\title{
Groundwater Quality Investigation Using Multivariate Analysis - Case Study: Western Nile Delta Aquifer, Egypt
}

\author{
Asaad M. Armanuos, Abdelazim Negm, and Oliver C. Saavedra Valeriano
}

\begin{abstract}
Groundwater is an important source of drinking water in Egypt. Therefore, it is very important to assess the quality of drinking water. The present study presents the multivariate statistical analysis of groundwater quality of western Nile Delta aquifer in order to investigate the factors controlling the groundwater quality. Nineteen Physicochemical parameters viz., Electrical conductivity (EC), Total dissolved solids (TDS), Total Hardness (TH), pH, Calcium (Ca), Magnesium (Mg), Sodium (Na), Potassium (K), Chloride (Cl), Sulphate $\left(\mathrm{SO}_{4}\right)$, Bicarbonate $\left(\mathrm{HCO}_{3}\right)$, Carbonate $\left(\mathrm{CO}_{3}\right)$, Iron (Fe), Manganese (Mn), Zinc ( $\mathrm{Zn})$, Cupper (Cu), Nickel (Ni), Nitrate $\left(\mathrm{NO}_{3}\right)$ and Ammonium $\left(\mathrm{NH}_{4}\right)$ are analyzed. From the correlation matrix analysis of groundwater quality parameters, strong correlation is observed among $K, C a$ and $C L$ versus EC. The same relations between $\mathrm{Mg}, \mathrm{Ca}, \mathrm{CL}$ versus $\mathrm{TDS}$, as well as weak and negative correlation are found among $\mathrm{HCO}_{3}, \mathrm{Fe}, \mathrm{Mn}$, $\mathrm{Zn}, \mathrm{Cu}, \mathrm{NH}_{4}, \mathrm{NO}_{3}$ with EC, TDS. Factor analysis is applied on the 19 parameters to investigate the origin of the water pollution sources. Multivariate analysis showed the existence of up to four significant factors which account for $77.0 \%$ of the total variance of hydrochemistry data. The first two factors can be initially assigned to mineralization, mining and salinity due to saltwater intrusion whereas the others originate as a result of industrial wastes, domestic wastes and wastes from agriculture activities. This work will provide policy makers and land use managers with knowledge of precise groundwater quality problems affecting the aquifer. It is recommended that concerned authorities should take the necessary actions to control the pollution sources of groundwater such as human activities, agricultural activities, and other industrial units.
\end{abstract}

Index Terms-Groundwater quality, multivariate analysis, nile delta aquifer, factor analysis.

\section{INTRODUCTION}

Groundwater is the main source for domestic, industrial and agriculture uses in most of the new reclaimed areas in the western Nile Delta region, which affect the groundwater quality. The Fresh water in the western Nile Delta concentrated in the central-eastern part, close to Rosetta branch. The concentration of $(\mathrm{Cl})$ and $\left(\mathrm{SO}_{4}\right)$ ions acquires the higher concentrations of the anions, where as the concentration of $(\mathrm{Na}),(\mathrm{Ca})$ and $(\mathrm{Mg})$ acquire the higher concentrations of the cations, Sharaky et al. [1]. However, the

Manuscript received December 11, 2014; revised May 4, 2015.

Asaad M. Armanuos and Abdelazim Negm are with Environmental Engineering Department, School of Energy and Environmental Engineering, Egypt-Japan University of Science and Technology, E-JUST, Alexandria, Egypt (e-mail: asaad.matter@ejust.edu.eg, amnegm@zu.edu.eg, abdelazim.negm@ejust.edu.eg).

Oliver C. Saavedra Valeriano is with the Department of Civil Engineering, Tokyo Institute of Technology (2-12-1 Oookayama, Meguro, Tokyo 152-0033, Japan. He is also with E-JUST, Egypt (e-mail: saavedra.o.aa@m.titech.ac.jp).
Nile Delta saturated zone lies beneath several land uses which reflect variations in the aquifer characteristics within the delta basin. The agricultural and industrial activities in the Nile Delta region affect the groundwater quality, Ramily [2]. On the other hand, Taha et al. [3] evaluated the water quality in the new communities south east the Nile Delta. The water resources include groundwater, surface water and drainage water in the new communities located at the South Eastern part of the Nile Delta, Egypt. The results showed that the available water resources were classified into different categories based on the content of major cations, anions and total dissolved salts. Moreover, the microbial content of drinking groundwater water in Kafr Al-Zayat region (Egypt) was assessed by Masoud [4]. The conducted factor analysis indicated that the microbial content is the most influential factor raising the variability of groundwater quality in the study area. Turbidity was strongly associated with is the most of the quality parameters and resulting from urban and agricultural runoff. The temporal and spatial variations of groundwater quality of the Northern Nile Delta aquifer using multivariate statistical techniques introduced by El Arabi et al. [5]. They found that four factors were controlling the groundwater quality within the study period of four years (2007-2010). Two of the factors were initially assigned to natural mineralization and saline whereas the others two were related to pollution as a result of agriculture and industrial activities. The ARCGIS was utilized to detect the spatial variations of the four factors. The study recommended a suitable environmental treatment for the industrial wastes.

Classification the groundwater quality or its type can offer great advantages especially in regional groundwater management and provides a short, quick processing, interpretation for a lot of complete hydrochemical data sets and concise presentation of the results. GIS spatial clustering technique is used to the hydrochemical data in order to identify over geographical space the different homogenous groundwater quality and type classes present in an area north the Nile Delta, [6]. Also, Mogren and Shehata [7] used GIS to present the groundwater vulnerability mapping of the Quaternary aquifer system in the North-Eastern part of Nile Delta. GIS layers have been created to adopt the most indicative criteria for investigating the groundwater degradation trends from sea level rise and seawater intrusion. Also, Subramani et al. [8] used the GIS to study the groundwater quality for Coonoor Taluk in Nilgiri District (India). The ground water quality analysis was carried out for the samples were collected and the results are presented in a GIS based water quality mapping. Moreover, Khan et al. [9] applied descriptive statistical measure and a partial correlation analysis to groundwater quality data set monitored 
in pre-monsoon and post-monsoon for three years to investigate seasonal variations of groundwater quality in India. Also, in India, Shivasharanappa and Srinivas [10] studied the seasonal variability of groundwater quality parameters in an industrial area for pre-monsoon and post-monsoon seasons for the years 2009, $2010 \& 2011$. Seventeen physicochemical parameters were analyzed. Factor analysis was applied on the data set to investigate the origin of the water pollution sources.

\section{STUDY AREA DISCRIPTION}

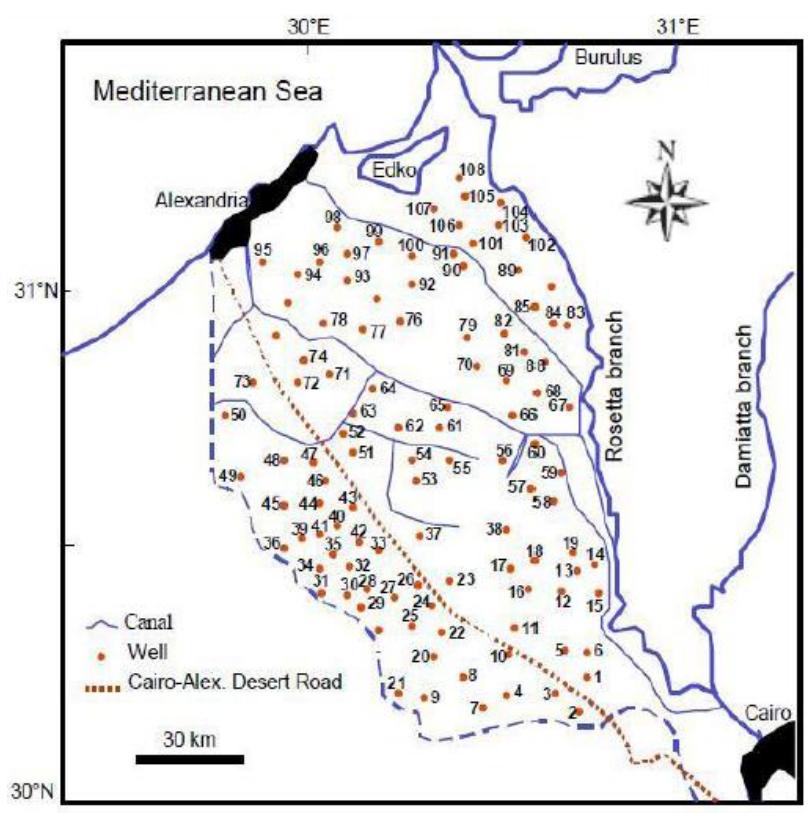

Fig. 1. Map of the study area [1].

The study area is located in western Nile Delta as shown in Fig. 1. Samples were collected from 108 wells and analyzed for physo-chemical parameters in RIGW 2007 by Sharaky et al. [1].

\section{MATERIALS AND METHODS}

\section{A. Chemical Parameters}

Sixteen hydro-chemical variables [1] including electrical conductivity (EC), total dissolved solids (TDS), $\mathrm{pH}$, calcium $(\mathrm{Ca})$, magnesium $(\mathrm{Mg})$, chloride $(\mathrm{Cl})$, nitrate $\left(\mathrm{NO}_{3}\right)$, sulfate $\left(\mathrm{SO}_{4}\right)$, iron $(\mathrm{Fe})$, sodium $(\mathrm{Na})$, potassium $(\mathrm{K})$, bicarbonate $\left(\mathrm{HCO}_{3}\right)$, manganese $(\mathrm{Mn})$, zinc $(\mathrm{Zn})$, cupper $(\mathrm{Cu})$ and ammonium $\left(\mathrm{NH}_{4}\right)$ were selected as variables inputs for Factor analysis.

\section{B. Used Tools}

The Statistical Packages for Social Sciences (SPSS) was used to carry out the statistical analyses. Correlation Matrix is as a first step in factor analysis is used to account for the degree of mutually shared variability between individual pairs of groundwater quality variables Perfect correlation coefficient is ranging 0.99 to 1.00 . Strong correlation coefficient is ranging 0.80 to 0.98 . Parameters showing correlation coefficients of $r>0.5-0.8$ are considered to be moderate correlation. Weak correlation coefficient is considered when $r<0.5$. The negative values show inverse relationships between chemical parameters. The strong to perfect correlation between the chemical parameters is an indication of common source. Factor analysis exposes the important factor responsible for variation in ground water quality eventually leads to sources identification of ground water pollution. Therefore, the factor analysis is applied to extract the most significant factors and to reduce the contribution of less significant variables to simplify even more of the data structure coming from factor analysis. In the present work, factor extraction was done by principal components; whereas, Varimax rotation with Kaiser Normalization was used for orthogonal rotation and results in factors that are uncorrelated. The factor scores that are computed for each observation which expresses the importance of each factor at that observation site outlined the importance of factor scores and their relations to potential of the processes described by each factor. Also, the spatial analysis module of ARCGIS 10.2 is used to plot the spatial distribution for groundwater quality parameters. Moreover, Inverse distance weighted (IDW) interpolation technique is used for spatial modeling. The IDW is an algorithm used to interpolate data spatially or estimate values between measurements. Each value estimated in an IDW interpolation is a weighted average of the surrounding sample points.

\section{RESULTS AND DISCUSSIONS}

\section{A. Spatial Variation of Groundwater Parameters}

Using ARC VIEW 10.2 the spatial interpolation was done on the basis of attribute values. Like TDS, $\mathrm{Cl}, \mathrm{Na}, \mathrm{Ca}, \mathrm{TH}, \mathrm{pH}$, $\mathrm{EC}, \mathrm{CO}_{3}, \mathrm{Fe}, \mathrm{NH}_{4}, \mathrm{Ni}$ and $\mathrm{Mn}$. For each parameter the spatial analysis was done and map was created as presented in Fig. 2 to Fig. 13.

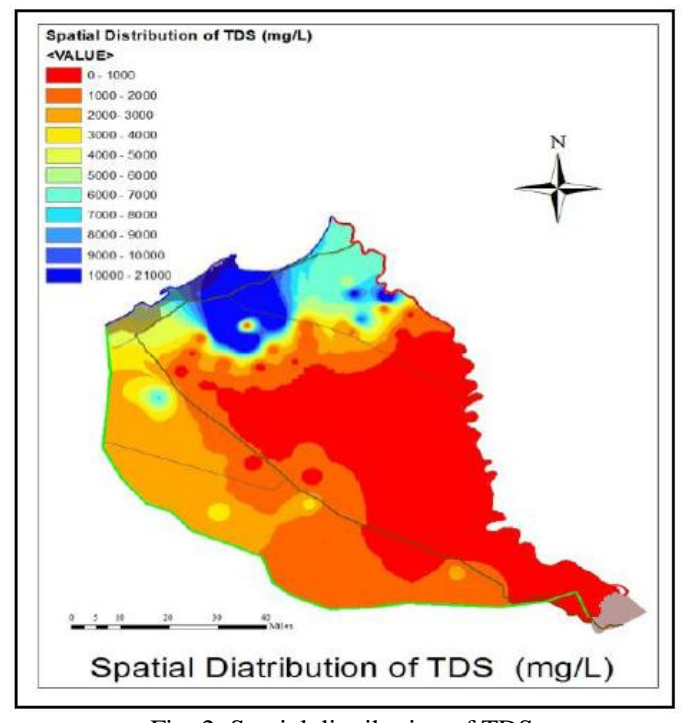

Fig. 2. Spatial distribution of TDS

Fig. 2 shows the spatial distribution of TDS in the study area and it is ranging from $430 \mathrm{mg} / \mathrm{l}$ to $24407 \mathrm{mg} / \mathrm{l}$ with an average of $2684.22 \mathrm{mg} / \mathrm{L}$. It is clear from the figure that high concentration of TDS is observed near the shore line of Mediterranean Sea in the north as a result of interaction between freshwater in the aquifer and saltwater from 
Mediterranean Sea, Sharaky et al. [1]. On the other hand, lower concentration is shown in eastern part which is attributed to the effect of seepage from Rosetta branch and irrigation canals. Moderate concentration is observed in western part of the study area.

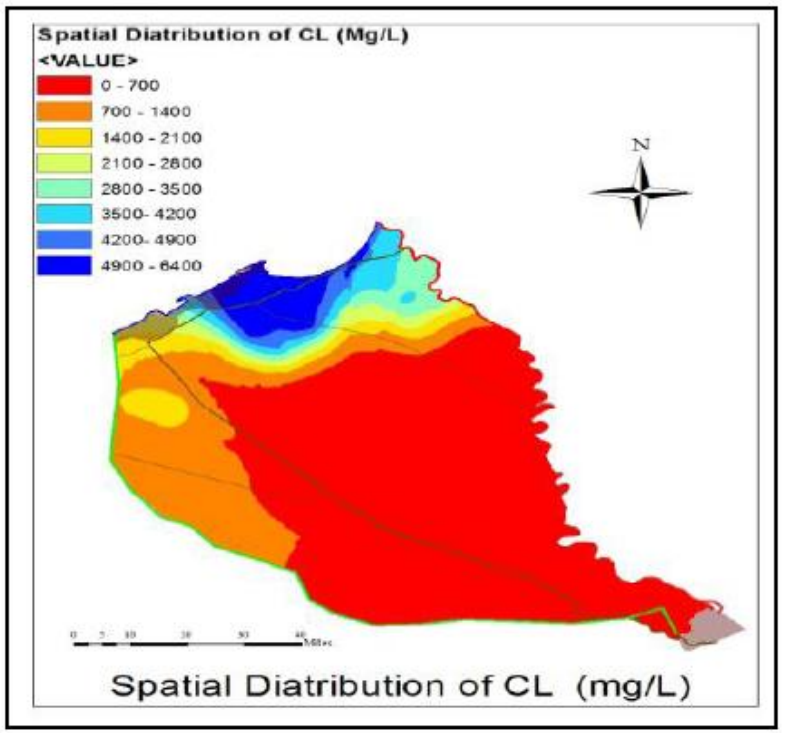

Fig. 3. Spatial distribution of $\mathrm{Cl}$.

Fig. 3 shows the spatial distribution of Chloride in the study area and it is fluctuating from $39 \mathrm{mg} / \mathrm{l}$ to $12173 \mathrm{mg} / \mathrm{l}$ with an average of $1000.31 \mathrm{mg} / \mathrm{L}$. High concentration of chloride is observed as $12173 \mathrm{mg} / \mathrm{l}$ near the northern part i.e, near the Mediterranean Sea, Sharaky et al. [1]. This may be due to either saltwater intrusion or to pollution from industrial or domestic wastes which finds its way to groundwater through seepage or inflation. Concentration of chloride in the central and eastern part decreases which is attributed to the expected high groundwater recharge from Rosetta Branch and irrigation canals.

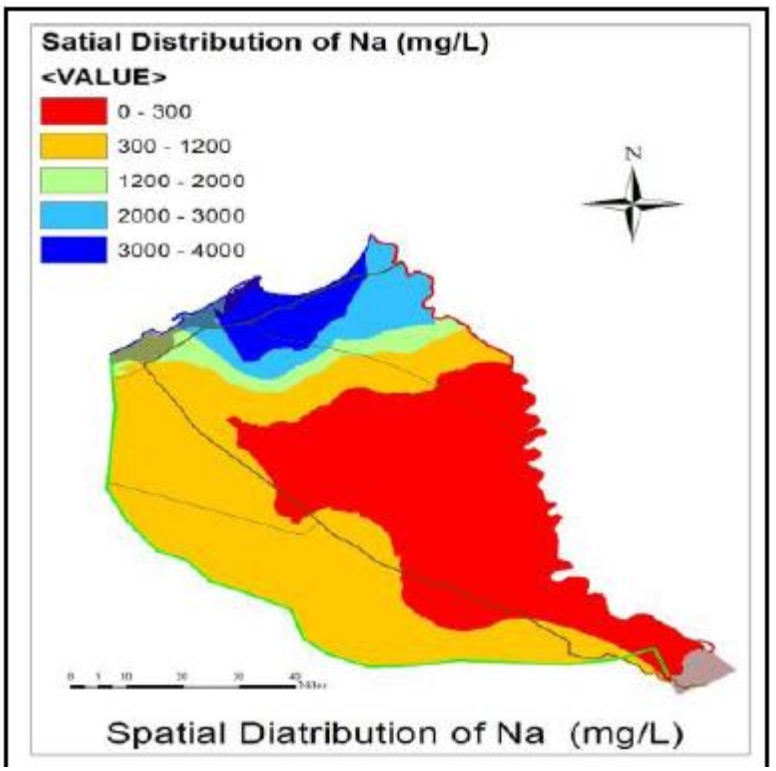

Fig. 4. Spatial distribution of Na.

Fig. 4 showed the spatial distribution of Sodium in the study area. It varies from $35 \mathrm{mg} / \mathrm{l}$ to $7774 \mathrm{mg} / \mathrm{l}$ with an average of $733.54 \mathrm{mg} / \mathrm{L}$. The major source of sodium content in the ground water is due to presence of salts. High concentration of Sodium $(7774 \mathrm{mg} / \mathrm{l})$ is observed in the northern part near the Mediterranean Sea due to seawater and freshwater interface and less recharge of freshwater from irrigation canals and River Nile, Sharaky et al. [1]. On the other hand, concentration of Sodium decreases gradually in the central and eastern part due to recharging from irrigation canals.

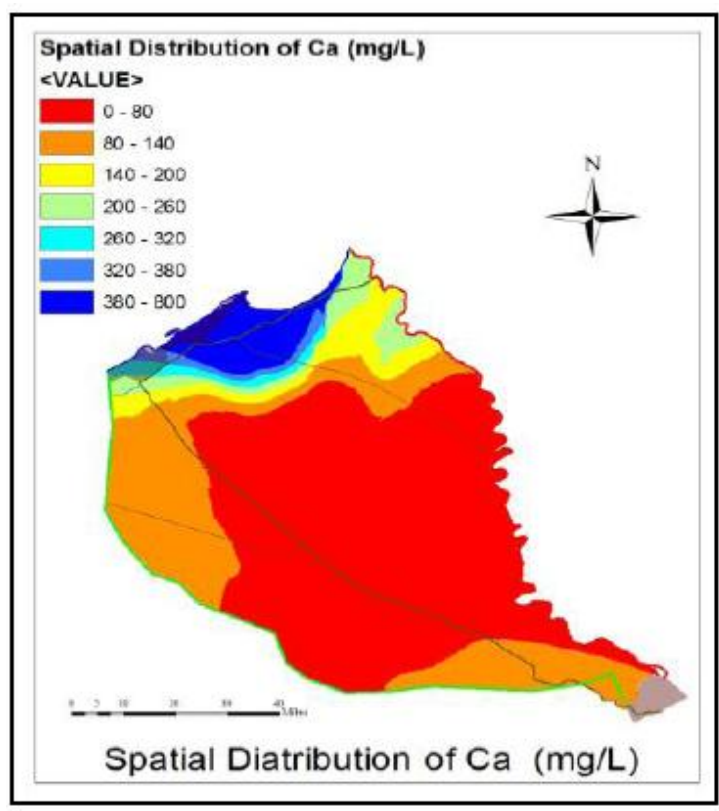

Fig. 5. Spatial distribution of Ca.

Fig. 5 presents the spatial distribution of Calcium in the study area and it is fluctuating from $12 \mathrm{mg} / \mathrm{l}$ to $1300 \mathrm{mg} / \mathrm{l}$ with an average of $97.84 \mathrm{mg} / \mathrm{L}$, Sharaky et al. [1]. Calcium occurs in water mainly due to the presence of limestone, gypsum, and dolomite and gypsi ferrous minerals. Higher values of calcium concentration are observed in northern part due to saltwater intrusion and degradation of aquifer sediments. On the other hand, concentration of calcium decreases in the eastern part of the study area because seepage of freshwater from irrigation canals and River Nile.

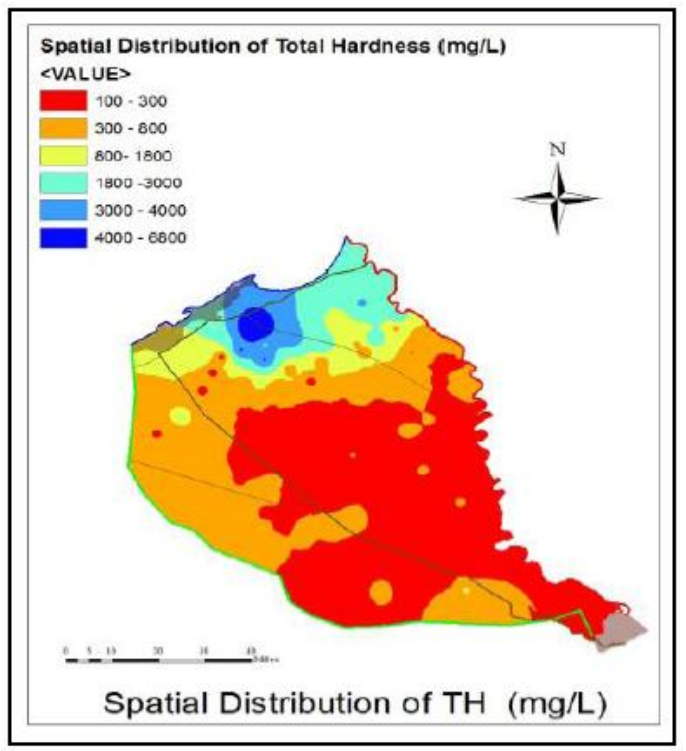

Fig. 6. Spatial distribution of TH.

Fig. 6 shows the spatial distribution of Total Hardness in the study area. It ranges between $113 \mathrm{mg} / 1$ to $6739 \mathrm{mg} / \mathrm{l}$ with 
an average of $612.84 \mathrm{mg} / \mathrm{L}$. Hardness in water is caused mainly due to the presence of carbonates and bicarbonates of calcium and magnesium, sulphate, chloride and nitrate. Total hardness in water is a content of calcium $\left(\mathrm{Ca}^{2+}\right)$ and magnesium $\left(\mathrm{Mg}^{2+}\right)$ as equivalent of $\mathrm{CaCO}_{3}$. High concentration of total hardness in Northern part is due to high concentration of calcium and magnesium whereas lower concentration in eastern part is due to the contribution of the continuous recharge of freshwater.

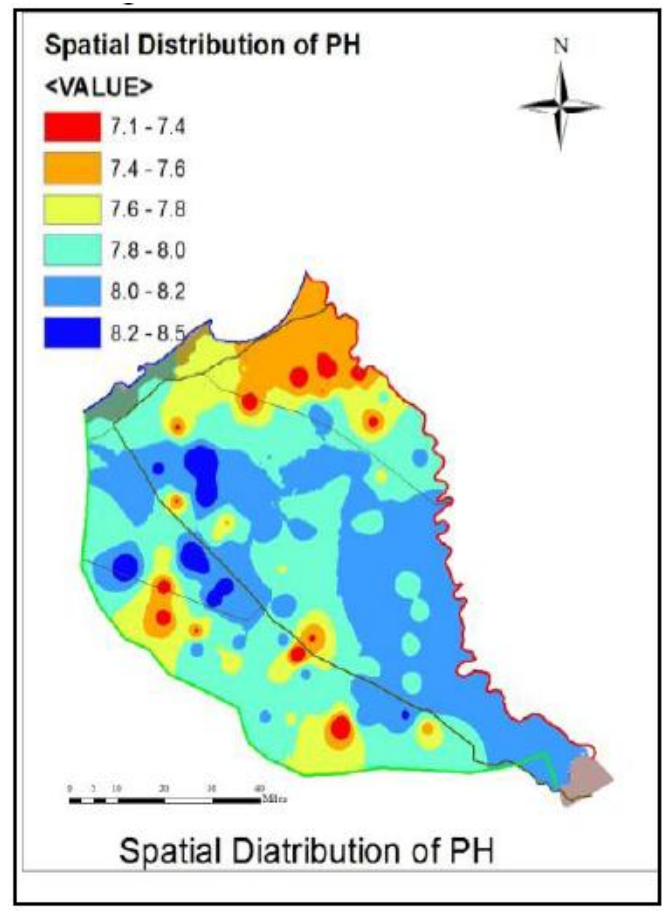

Fig. 7. Spatial distribution of $\mathrm{pH}$.

Similarly, Fig. 7 shows the spatial distribution of $\mathrm{pH}$ in the study area. The $\mathrm{pH}$ varies between 7.11 and 8.65 with an average of 7.90 . The $\mathrm{pH}$ parameter is one of the most important operational water quality parameters. High values of $\mathrm{pH}$ are observed only in eastern part while lower values are observed in western and northern part of the study area.

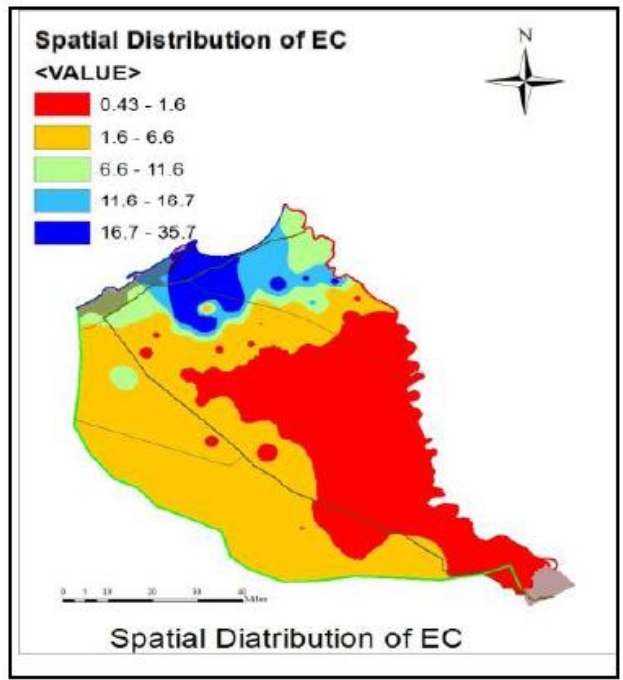

Fig. 8. Spatial distribution of EC.

Fig. 8 indicates that the Electrical Conductivity (EC) in the study area ranges between 0.43 and $37.5 \mu \mathrm{S} / \mathrm{cm}$ at $30^{\circ} \mathrm{C}$ with a mean of $4.23 \mu \mathrm{S} / \mathrm{cm}$. It can be seen from the figure that high concentration of EC is observed in Northern part near the Mediterranean Sea with high values of dissolved salts. On the other hand lower concentration concentrated in the all southern and eastern part of the study area.

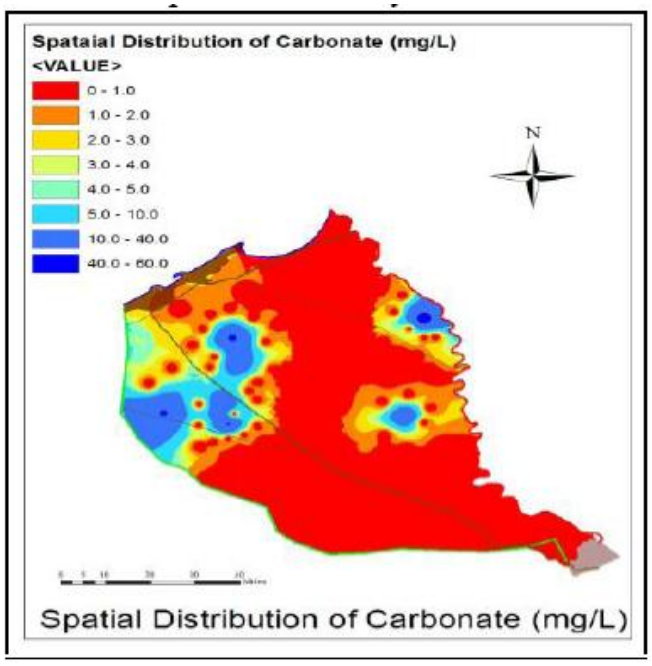

Fig. 9. Spatial distribution of $\mathrm{HCO}_{3}$.

Fig. 9 indicates that Carbonate $\left(\mathrm{CO}_{3}\right)$ in the study area ranges between 0.0 and $60.0 \mathrm{mg} / \mathrm{L}$ with a mean of $2.53 \mathrm{mg} / \mathrm{L}$. Carbonates are found in groundwater due to rock content, in most sedimentary rocks, and even some igneous and metamorphic rocks. Lower concentration of Carbonate is observed in Northern and southern part while higher concentration is observed in the all eastern and western part of the study area.

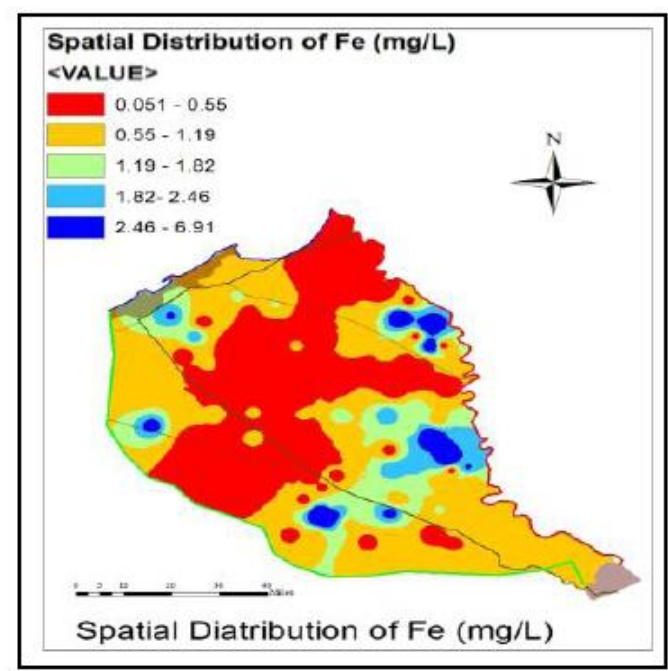

Fig. 10. Spatial distribution of Fe.

Fig. 10 shows that the Iron $(\mathrm{Fe})$ in the study area ranges between 0.05 and $7.0 \mathrm{mg} / \mathrm{L}$ with a mean of $0.85 \mathrm{mg} / \mathrm{L}$. The iron occurs naturally in the aquifer but levels in groundwater can be increased by dissolution of ferrous borehole and hand pump components. Most of the study area exhibits low concentration of iron except small areas in eastern and western part that show high or moderate concentrations.

Fig. 11 shows that Ammonium $\left(\mathrm{NH}_{4}\right)$ in the study area is ranges between 0.01 and $0.5 \mathrm{mg} / \mathrm{L}$ with a mean of $0.035 \mathrm{mg} / \mathrm{L}$. Ammonia may be present in groundwater as a result of the degradation of naturally occurring organic matter or manmade sources. Also originate from nitrogen-fertilizer 
application, livestock operations, industrial processes, sewage infiltration, and cement mortar pipe lining. Higher values of Ammonium are concentrated in northern and southern part whereas lowest values are presented in eastern and western part of the study area.

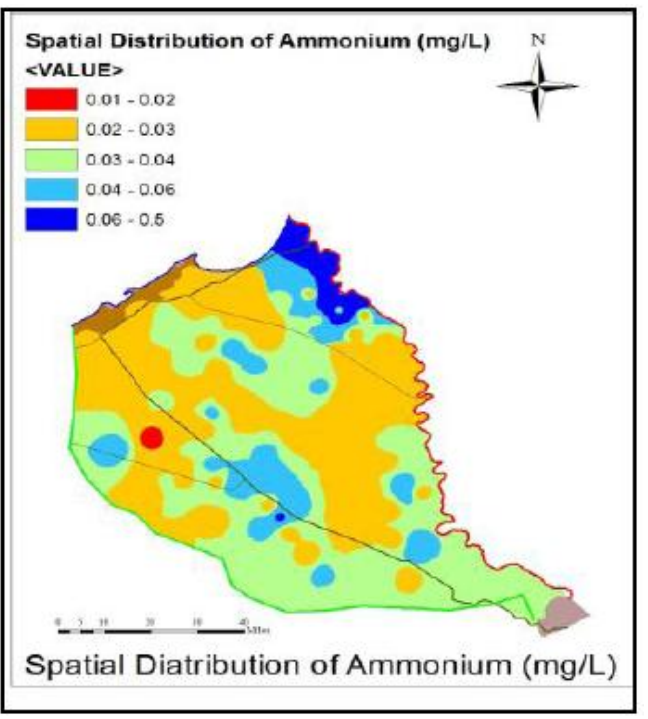

Fig. 11. Spatial distribution of $\mathrm{NH}_{4}$.

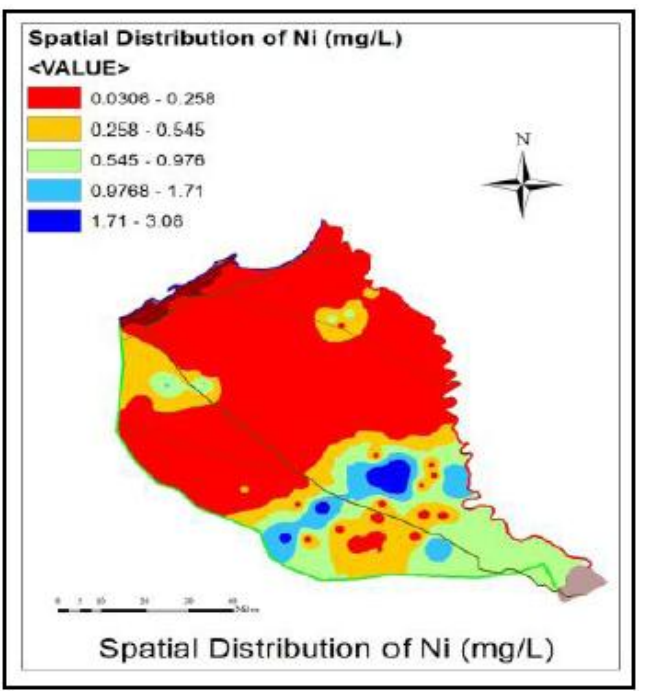

Fig. 12. Spatial distribution of Ni.

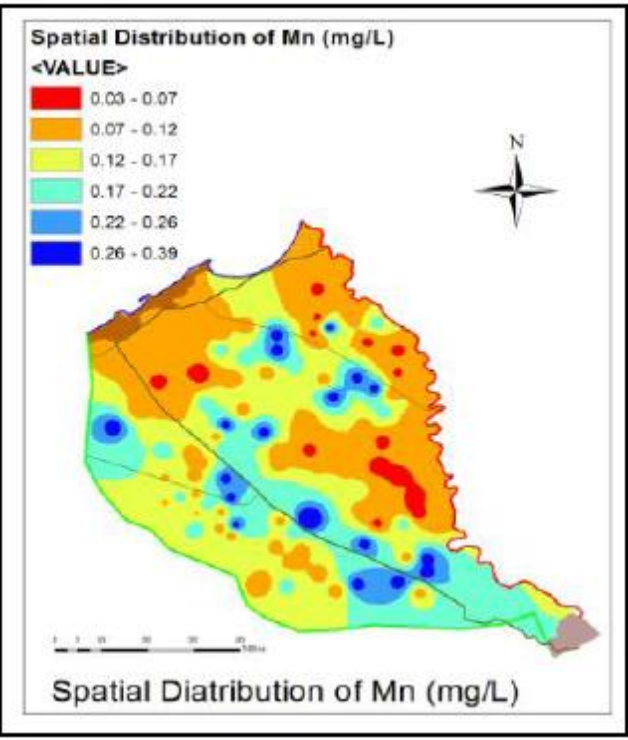

Fig. 13. Spatial distribution of Mn.
Fig. 12 shows that Nickel (Ni) ranges between 0.03 and 3.1 $\mathrm{mg} / \mathrm{L}$ with a mean of $0.33 \mathrm{mg} / \mathrm{L}$. Nickel occurs naturally in soils, groundwater, and surface water. Nickel (Ni) is often used in electroplating, stainless steel and alloy products, mining, and refining. Lower values of Nickel are concentrated in central and north part whereas higher values are observed in southern part of the study area.

Finally, Fig. 13 shows that Manganese (Mn) ranges between 0.03 and $0.4 \mathrm{mg} / \mathrm{L}$ with a mean of $0.14 \mathrm{mg} / \mathrm{L}$. Manganese occurs naturally as a mineral from sediment and rocks or from mining and industrial waste. Lower values of Manganese are observed in eastern and northern part whereas higher values are concentrated in southern part of the study area.

\section{B. Factor Analysis}

The correlation matric as a first step of the factor analysis is presented in Table I.

From Table I, perfect correlation is found between TDS and EC, and with $\mathrm{Na}$ and EC. The correlation matrix shows strong correlation between $\mathrm{Mg}, \mathrm{Ca}, \mathrm{CL}$ and EC. Similar relations are found between $\mathrm{Na}, \mathrm{Mg}, \mathrm{Ca}$, and $\mathrm{CL}$ with TDS and among $\mathrm{Na}$ and $\mathrm{K}, \mathrm{Mg}$ and $\mathrm{Na}$, and with $\mathrm{CL}$ and $\mathrm{Na}$ as well. Strong correlation is found between $\mathrm{Ca}$ and $\mathrm{Mg}, \mathrm{CL}$ and $\mathrm{Mg}$, $\mathrm{SO}_{4}$ and $\mathrm{Ca}$, and with $\mathrm{CL}$ and $\mathrm{Ca}$. Moderate correlation is observed between $\mathrm{K}$ and $\mathrm{SO}_{4}$ with $\mathrm{EC}, \mathrm{K}$ and TDS, and with $\mathrm{SO}_{4}$ and TDS. Similar correlation is found between $\mathrm{Mg}, \mathrm{CL}$ and $\mathrm{K}$, and with $\mathrm{Ca}, \mathrm{SO}_{4}$ and $\mathrm{Na}$. and among $\mathrm{SO}_{4}, \mathrm{HCO}_{3}$ and $\mathrm{Mg}$, and with $\mathrm{SO}_{4}$ and $\mathrm{C}$ as well. On the other hand, Table I shows negative and weak correlation between $\mathrm{HCO}_{3}, \mathrm{Fe}, \mathrm{Mn}$, $\mathrm{Zn}, \mathrm{Cu}, \mathrm{NH}_{4}$ and $\mathrm{NO}_{3}$ with EC, TDS, pH, K, Na, Mg, Ca and CL.

The examination of the Scree plot shown in Fig. 14 indicated that four factors were responsible for the variance of 19 parameters.

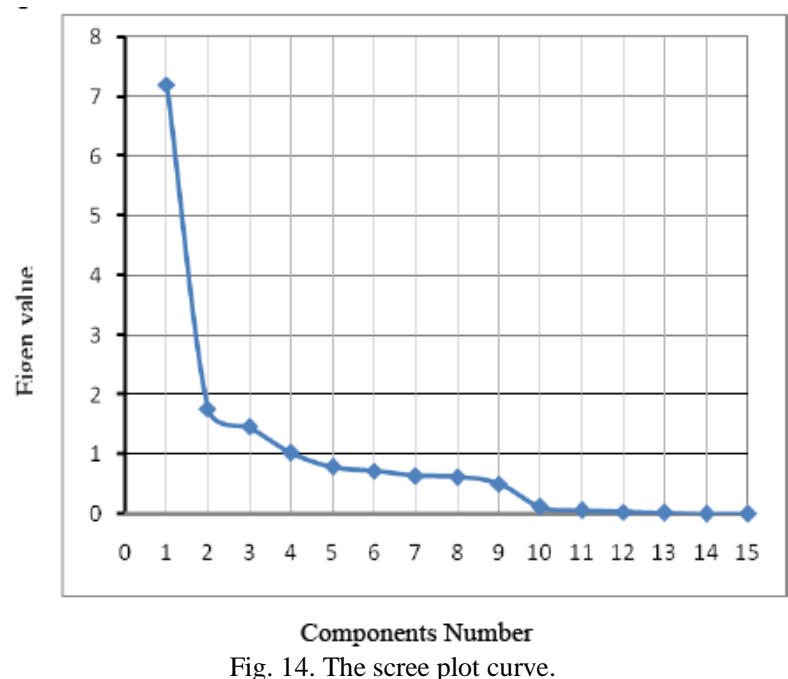

Table II presents the loading of each variable under each one of the four factors. In factor analysis the first factor usually represents the most important process or mix processes controlling the hydrochemistry. It has the highest eigenvalue and accounts for the high variance among the factors. In this study, the first factor which accounts for about $47.2 \%$ of the variance has highest positive loadings for EC, TDS, K, $\mathrm{Ca}, \mathrm{Mg}, \mathrm{Na}, \mathrm{CL}$ and $\mathrm{SO}_{4}$. 
TABLE I: CORRELATION MATRIX

\begin{tabular}{|c|c|c|c|c|c|c|c|c|c|c|c|c|c|c|c|c|}
\hline & EC & TDS & $\mathrm{pH}$ & $\mathrm{K}$ & $\mathrm{Na}$ & $\mathrm{Mg}$ & $\mathrm{Ca}$ & CL & $\mathrm{SO}_{4}$ & $\mathrm{HCO}_{3}$ & $\mathrm{Fe}$ & $\mathrm{Mn}$ & $\mathrm{Zn}$ & $\mathrm{Cu}$ & $\mathrm{NH}_{44}$ & $\mathrm{NO}_{3}$ \\
\hline $\mathrm{EC}$ & 1.0 & & & & & & & & & & & & & & & \\
\hline $\mathrm{pH}$ & -.41 & -.38 & 1.0 & & & & & & & & & & & & & \\
\hline $\mathrm{K}$ & .75 & .76 & -.34 & 1.0 & & & & & & & & & & & & \\
\hline $\mathrm{Na}$ & .99 & .98 & -.41 & .80 & 1.0 & & & & & & & & & & & \\
\hline $\mathrm{Mg}$ & .94 & .95 & -.34 & .62 & .90 & 1.0 & & & & & & & & & & \\
\hline $\mathrm{Ca}$ & .84 & .84 & -.35 & .44 & .78 & .86 & 1.0 & & & & & & & & & \\
\hline $\mathrm{CL}$ & .96 & .98 & -.40 & .79 & .95 & .93 & .82 & 1.0 & & & & & & & & \\
\hline $\mathrm{SO}_{4}$ & .77 & .79 & -.30 & .42 & .75 & .74 & .91 & .74 & 1.0 & & & & & & & \\
\hline $\mathrm{HCO}_{3}$ & .46 & .49 & -.04 & .31 & .45 & .52 & .22 & .41 & .12 & 1.0 & & & & & & \\
\hline $\mathrm{Fe}$ & -.08 & -.08 & .12 & -.06 & -.10 & -.04 & -.02 & -.08 & -.02 & -.07 & 1.0 & & & & & \\
\hline Mn & -.06 & -.05 & .01 & -.01 & -.05 & -.06 & -.08 & -.05 & -.07 & .08 & -.24 & 1.0 & & & & \\
\hline $\mathrm{Zn}$ & .02 & .02 & -.06 & -.01 & .01 & .06 & .06 & .05 & 0.0 & -.11 & .25 & -.36 & 1.0 & & & \\
\hline $\mathrm{Cu}$ & .01 & .03 & .28 & .10 & -.02 & .04 & .04 & .04 & .01 & .08 & .28 & -.14 & .12 & 1.0 & & \\
\hline $\mathrm{NH}_{4}$ & .15 & .20 & -.15 & -.02 & .20 & .10 & .17 & .13 & .41 & -.05 & -.07 & .00 & -.02 & -.22 & 1.0 & \\
\hline $\mathrm{NO}_{3}$ & .31 & .30 & -.14 & .25 & .30 & .37 & .29 & .28 & .24 & .09 & -.04 & -.20 & .14 & .12 & .17 & 1.0 \\
\hline
\end{tabular}

TABLE II: ROTATED COMPONENT MATRIX

Component

\begin{tabular}{|c|c|c|c|c|}
\hline parameters & 1 & 2 & 3 & 4 \\
\hline $\mathrm{EC}$ & 0.984 & 0.008 & -0.089 & 0.053 \\
\hline TDS & 0.991 & -0.009 & -0.060 & 0.078 \\
\hline $\mathrm{pH}$ & -0.373 & -0.176 & 0.704 & $0-.009$ \\
\hline $\mathrm{K}$ & 0.774 & 0.011 & -0.124 & -0.263 \\
\hline $\mathrm{Na}$ & 0.968 & -0.006 & -0.125 & 0.054 \\
\hline $\mathrm{Mg}$ & 0.956 & 0.022 & -0.006 & 0.041 \\
\hline $\mathrm{Ca}$ & 0.841 & 0.092 & 0.008 & 0.337 \\
\hline $\mathrm{CL}$ & 0.973 & 0.035 & -0.082 & 0.025 \\
\hline $\mathrm{SO}_{4}$ & 0.767 & 0.045 & 0.021 & 0.561 \\
\hline $\mathrm{HCO}_{3}$ & 0.521 & -0.296 & 0.154 & -0.375 \\
\hline $\mathrm{Fe}$ & -0.050 & 0.522 & 0.475 & 0.038 \\
\hline $\mathrm{Mn}$ & -0.051 & $-\mathbf{0 . 7 3 7}$ & -0.066 & -0.026 \\
\hline $\mathrm{Zn}$ & 0.015 & 0.794 & -0.051 & -0.065 \\
\hline $\mathrm{Cu}$ & 0.108 & 0.182 & 0.769 & -0.198 \\
\hline $\mathrm{NH}_{4}$ & 0.104 & -0.062 & -0.140 & 0.814 \\
\hline Eigen value & 7.078 & 1.615 & 1.414 & 1.361 \\
\hline Variance $(\%)$ & 47.189 & 10.767 & 9.424 & 9.073 \\
\hline ulative variance (\%) & 47.189 & $\mathbf{5 7 . 9 5 6}$ & 67.380 & 76.453 \\
\hline
\end{tabular}

The Second factor accounts for about $10.77 \%$ in the hydrochemistry and has high positive loading for Fe, Mn and
$\mathrm{Zn}$. The third factor accounts for about $9.42 \%$ in the hydrochemistry and has high positive loadings for $\mathrm{pH}, \mathrm{Fe}$ and $\mathrm{Cu}$. The fourth factor accounts for about $9.07 \%$ in the hydrochemistry and has high positive loadings for $\mathrm{NH}_{4}$ and $\mathrm{SO}_{4}$.

\section{Factor Analysis Maps}

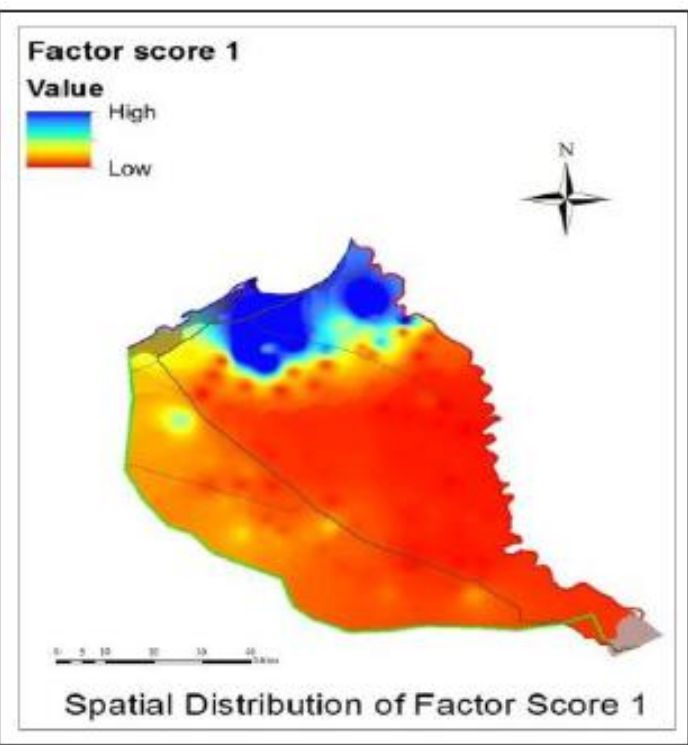

Fig. 15. Distribution map of factor score 1

Fig. 15 shows the spatial distribution of factor score 1 . Factor 1 has Eigen value with 7.078 and $47.189 \%$ of the variance. It has high loadings on $\mathrm{EC}, \mathrm{TDS}, \mathrm{K}, \mathrm{Na}, \mathrm{Mg}, \mathrm{Ca}, \mathrm{CL}$ and $\mathrm{SO}_{4}$, moderate loadings on $\mathrm{pH}$ and $\mathrm{HCO}_{3}$, low loadings on $\mathrm{Fe}, \mathrm{Mn}, \mathrm{Zn}, \mathrm{Cu}, \mathrm{NH}_{4}$.

It suggests that the quality of ground water is mainly controlled by high loading parameters. The high loading of TDS, $\mathrm{Ca}, \mathrm{Na}$, and $\mathrm{CL}$ is due to saltwater intrusion from the 
Mediterranean Sea. The high loading of $\mathrm{SO}_{4}$ is related to the long-history of evaporation process, the high value of $\mathrm{K}$ suggests pollution from application of potash fertilizers to agricultural lands. It is shown from Fig. 15 that, the high loading for factor number one is in the Northern part of the study area near the Mediterranean Sea.

The moderate loading of $\mathrm{pH}$ represents solubility of minerals. It is shown from Fig. 15 that, the moderate loading for factor number one is in the Western and Southern part of the study area. The combination of $\mathrm{Fe}, \mathrm{Mn}, \mathrm{Zn}$ and $\mathrm{Cu}$ indicates weathering of country rocks. It is shown from Fig. 15 that, the low loading for factor number one is in the central and Eastern part of the study area.

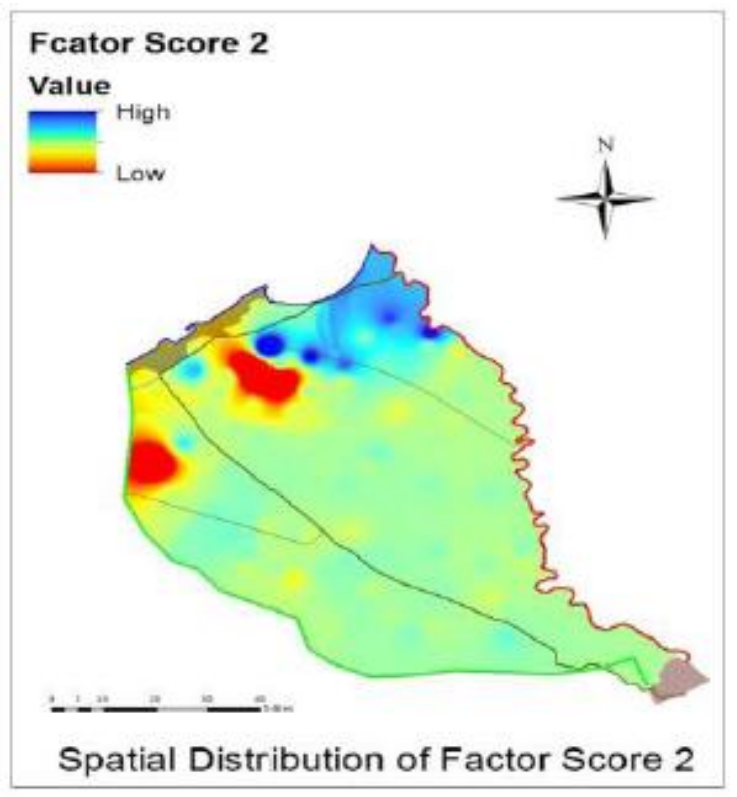

Fig. 16. Distribution map of factor score 2.

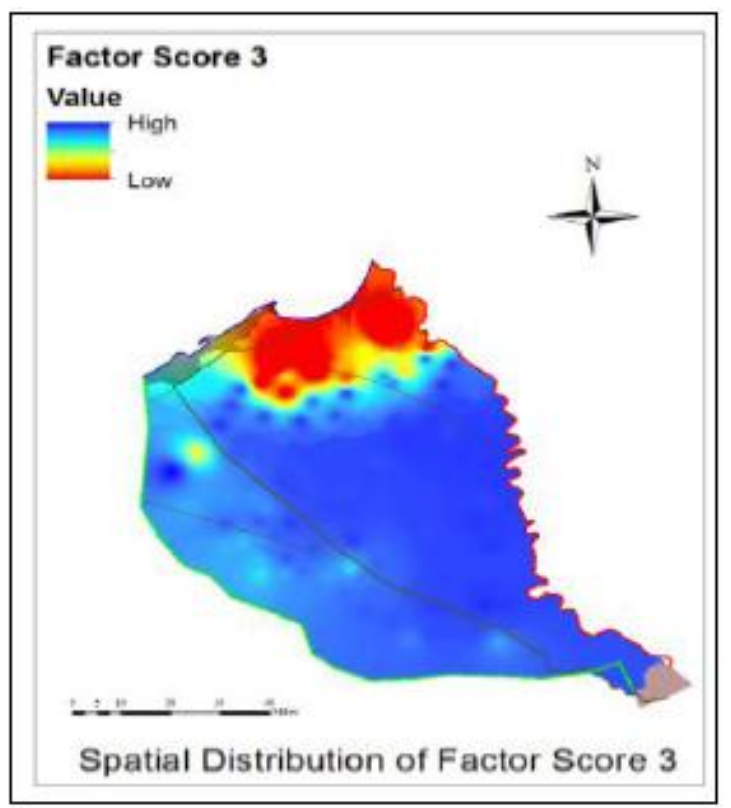

Fig. 17. Distribution map of factor score 3.

Fig. 16 shows the spatial distribution of factor score 2. Factor 2 has eigen values of 1.62 and $10.77 \%$ of the variance. It has high loadings on $\mathrm{Fe}, \mathrm{Mn}$ and $\mathrm{Zn}$, moderate loading on $\mathrm{pH}, \mathrm{Cu}, \mathrm{HCO}_{3}$ and low loadings on EC, TDS, K, Na, Mg, Ca, $\mathrm{CL}$ and $\mathrm{SO}_{4}$.
The high loading for $\mathrm{Fe}, \mathrm{Mn}$ and $\mathrm{Zn}$ component and it is responsible for salinity due to cation-exchange processes at soil water interface and industrial wastes. Iron loading may be due to dissolution of lithogenic materials. It is clear from the figure that high value for factor 2 is concentrated in Northern part from the study area.

Moderate loading is concentrated in the central, Eastern and Southern part of the study area. On the other hand, low loading is concentrated in Western North part of the study area.

Fig. 17 shows the spatial distribution of factor score 3 . Factor 3 having Eigen value with 1.414 and $9.424 \%$ of the variance, has high loadings on $\mathrm{pH}, \mathrm{Fe}$ and $\mathrm{Cu}$, low loadings on EC, TDS, K, Na, Mg, Ca, CL, $\mathrm{HCO}_{3}, \mathrm{Mn}, \mathrm{Zn}, \mathrm{NH} 4$ and $\mathrm{SO}_{4}$.

The high loading for $\mathrm{Fe}$ and $\mathrm{Cu}$ is due to salinity from cation-exchange processes at soil water interface and industrial wastes, Iron loading may be due to dissolution of lithogenic materials. The moderate loading $\mathrm{pH}$ represents solubility of minerals. It can be clear from the figure that high value for factor 3 is concentrated in Eastern part from the study area.

Moderate loading is concentrated in the Northern part of the study area with a small area, whereas Low loading is concentrated in the Northern part of the study area.

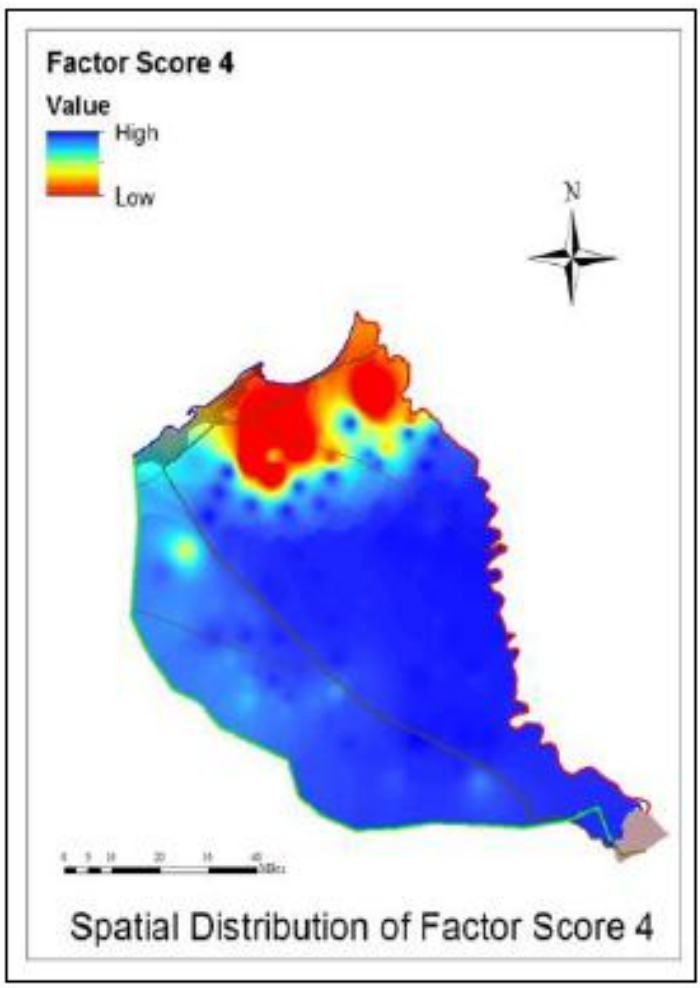

Fig. 18. Distribution map of factor score 4

Fig. 18 shows the spatial distribution of factor score 4 . Factor 4 has Eigen value with 1.36 and $9.07 \%$ of the variance. It has high loadings on $\mathrm{SO}_{4}$ and $\mathrm{NH}_{4}$, moderate loadings on $\mathrm{K}$, $\mathrm{Ca}$ and $\mathrm{Cu}$ and low loadings on EC, TDS, $\mathrm{pH}, \mathrm{Na}, \mathrm{Mg}, \mathrm{CL}$, $\mathrm{Fe}, \mathrm{Mn}$ and $\mathrm{Zn}$.

The high Loading of $\mathrm{SO}_{4}$ is related to the long-history of evaporation process while the high value of $\mathrm{NH}_{4}$ suggests pollution from application of potash fertilizers to agricultural lands. It can be clear from the Fig. 18 that the high loading for factor 4 was concentrated in eastern, central and southern part 
from the study area.

The moderate loading is concentrated in the Northern part of the study area with a small area. On the other hand the low loading is concentrated in the Northern part of the study area.

\section{CONCLUSIONS}

The spatial distribution for groundwater quality parameters is done using the spatial analyst module in ARCGIS 10.2 software. Inverse distance weighted (IDW) interpolation technique is used for spatial modeling. The Statistical Packages for Social Sciences (SPSS) is used to carry out the statistical analysis. Both correlation and factor analysis are conducted. Correlation among the investigated parameters varied from perfect to weak. The factor analysis is applied to identify the origin of the water pollution sources. The multivariate analysis showed the existence of up to four significant factors which account for $77.0 \%$ of the total variance of hydrochemistry data. The first factor which accounts for about $47.2 \%$ of the total variance assigned to salinity due to saltwater intrusion from the Mediterranean Sea The second factor accounts for $10.77 \%$ of the total variance and it is responsible for salinity due to mineral from sediment and rocks or from mining, industrial waste, and corroding metal. The third factor accounts for $9.42 \%$ of the total variance and it is responsible for salinity due to cation-exchange processes at soil water interface, industrial and domestic waste, solubility of minerals, and dissolution of lithogenic materials. The four factor accounts for $9.07 \%$ of the total variance and related to long-history of evaporation process and pollution from application of fertilizers and pesticides to agricultural lands.

\section{RECOMMENDATION}

It is recommended that concerned authorities should take the necessary actions to control the pollution sources of groundwater such as human activities, agricultural activities, and other industrial units. These actions may include environmental treatment of the industrial and domestic wastes as well as regularly environmental check for the industrial and human activities is highly recommended. Also, most contaminated areas such as those near of the shoreline of the Mediterranean Sea should benefit as the first priority from any monitoring programs, desalination and development projects. Moreover, awareness of the concerned people should be increased to maintain and preserve the groundwater quality.

\section{ABBREVIATIONS}

Electrical conductivity (EC), Total dissolved solids (TDS), Total Hardness (TH), Calcium (Ca), Magnesium (Mg), Sodium (Na), Potassium (K), Chloride (CL), Sulphate $\left(\mathrm{SO}_{4}\right)$, Bicarbonate $\left(\mathrm{HCO}_{3}\right)$, Carbonate $\left(\mathrm{CO}_{3}\right)$, Iron $(\mathrm{Fe})$, Manganese $(\mathrm{Mn})$, Zinc ( $\mathrm{Zn})$, Cupper $(\mathrm{Cu})$, Nickel $(\mathrm{Ni})$, Nitrate $\left(\mathrm{NO}_{3}\right)$ and Ammonium $\left(\mathrm{NH}_{4}\right)$.

\section{ACKNOWLEDGMENTS}

The first author would like to thank the Egyptian Ministry of Higher Education (MoHE) for providing him the financial support (PhD scholarship) for this research as well as the Egypt Japan University of Science and Technology (E-JUST) for offering the facility and tools needed to conduct this work. This work was partially supported by JSPS "Core-to-Core Program, B.Asia-Africa Science Platforms.

\section{REFERENCES}

[1] A. M. Sharaky, S. A. Atta, A. S. E. Hassanein, and K. M. A. Khallaf, "Hydrogeochemistry of groundwater in the Western Nile Delta aquifers, Egypt," presented at 2007 ICGT Conf., Cairo University, March 19-21, 2007.

[2] I. M. E. Ramily, "Hydrogeological and water quality characteristics of the sturated zone beneath the various land uses in the Nile Delta region, Egypt," in Proc. Rabat Symposium S4, April-May 1997, IAHS Publ. no. 243 .

[3] A. A. Taha, A. S. E. Mahmoudi, and I. M. El-Hadda, "Evaluation of the water quality in new communities South East the Nile Delta, Egypt," Emirates Journal for Engineering Research, vol. 8, no. 2, pp. 51-67, 2003.

[4] A. A. Masoud, "Spatio-temporal evaluation of the groundwater quality in Kafr Al-Zayat district, Egypt," Hydrol. Process, vol. 27, issue 20, pp. 2987-3002, Wiley Online Library, 2013.

[5] N. E. Arabi, Y. Idris, and A. Fekry, "Temporal and spatial change detection of variations in the groundwater composition by multivariate statistical techniques," New York Science Journal, vol. 6, no. 11, 2013

[6] Y. A. Idris, "A GIS-based spatial classification technique to identify the groundwater quality and type classes," Journal of American Science, vol. 9, no. 12, 2013

[7] S. Mogren and M. Shehata, "Groundwater vulnerability and risk mapping of the quaternary aquifer system in the northeastern part of the Nile Delta, Egypt," International Research Journal of Geology and Mining (IRJGM), vol. 2, no. 7, pp. 161-173, September 2012.

[8] T. Subramani, S. Krishnan, and P. K. Kumaresan, "Study of groundwater quality with GIS application for Coonoor Taluk in Nilgiri district," International Journal of Modern Engineering Research, vol. 2, issue 3, pp. 586-592, ISSN: 2249-6645, May-June 2012.

[9] M. M. A. Khan, R. Umar, M. A. Baten, H. Lateh, and A. A. Kamil, "Seasonal variations in groundwater quality: A statistical approach," International Journal of the Physical Sciences, vol. 7, no. 25, pp. 4026-4035, June 29, 2012.

[10] Shivasharanappa and P. Srinivas, "Studies on seasonal variation of ground water quality using multivariate analysis for Bidar urban \& ITS industrial area (Kanataka-State, INDIA)," International Journal of Research in Engineering and Technology, vol. 2, no. 13, pp. 252-261, 2013.

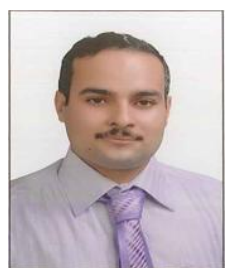

Asaad Mater Asaad Armanuos is an assistant lecturer in Irrigation and Hydraulics Engineering Department, Civil Engineering Department, Faculty of Engineering, Tanta University, Egypt. He is a $\mathrm{PhD}$ student at Environmental Engineering Department, Egypt-Japan University of Science and Technology (E-JUST), since Sep. 2014. His has a BSc in civil engineering (2008) with very good degree with honor, the MSc degree in groundwater contamination transport with title use of double sheet piles to control the contaminant transport through the Soil (2014). His research areas are wide to include groundwater, hydrology, water resources, contaminant transport, groundwater modeling, hydrological model, ARCGIS, groundwater quality, groundwater quantity and saltwater intrusion.

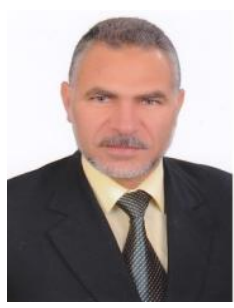

Abdelazim Negm was born in Sharkia, Egypt. His background is civil engineering because he was graduated from Irrigation and Environmental Engineering Dept. in 1985. Prof. Negm has got his M.Sc. from Ain Shams University in 1990 in hydrology of the Nile Basin. He got the PhD degree in 1990 in hydraulics.

Currently, he is a professor of water resources in Egypt-Japan University for Science and Technology (E-JUST) since Oct. 2012 and the chairman of the Environmental Engineering Dept. at E-JUST since Feb. 17, 2013. He worked as a demonstrator in Faculty of Engineering, Zagazig University in 1986 and continued till he occupied the position of the vice dean for Academic and 
Student Affair. He was promoted as a professor of hydraulics. His research areas are wide to include hydraulic, hydrology and water resources. He published about 200 papers in national and international Journals and conferences. He is listed in (a) Marquis Who is Who?, (b) IBC's 2000 Outstanding Intellectuals of the 21st Century, and (c) ABI directory for his achievement in the field of Hydraulics and Water Resources. He participated in more than 55 conferences. He has awarded the prizes of best papers three times. He participates in the two EU funded international projects.

Oliver C. Saavedra Valeriano is a $\mathrm{PhD}$ in civil engineering (applied hydrology oriented). He is an associate professor at Tokyo Institute of Technology and an adjunct professor to E-JUST since January 2010 to present.

$\mathrm{He}$ received his MSc in groundwater in 2002, Eberhard Karl University of Tübingen, Germany and the BSc. in civil engineering in 1998, Bolivian Private University, Bolivia.
He has four years experience in teaching advanced hydrology, GIS, water resources management lectures at graduate school. His major research interests are in development of decision supporting tools for water resources management including optimal dam operation, flood control.

$\mathrm{He}$ is a project coordinator of Integrated Water Resources and Environmental Management for Asian and African Mega-delta under Climate Change Effects. 